A L I Z A L U F T

\title{
Religion in Vichy France: How Meso-Level Actors Contribute to Authoritarian Legitimation
}

\begin{abstract}
Research on authoritarian legitimation suggests that rulers seek support through ideological, personalistic, performance-based, and procedural strategies. Typically, however, this work only considers the dynamics of legitimation between rulers and civilians. In contrast, this paper suggests that meso-level actors play a critical role in shaping legitimation from both above and below. Through an historical analysis of the French episcopate's support for the Vichy regime from I 940 to I 942 , I identify four practices that bolstered Vichy's attempts to accrue legitimacy and simultaneously identify the consequences of these practices for the Church's relationship with Jews. Public endorsements by the religious authorities for Marshal Pétain, their cooperation with the Vichy administration, the expression of shared values, and common rhetoric all contributed to the regime's legitimation process while leading to a concomitant decline in the hierarchy's ties to the rabbinate. These results suggest that attention to meso-level actors brings into relief important dynamics about how legitimation processes unfold in authoritarian settings while simultaneously contributing to research on the Holocaust in France.
\end{abstract}

Keywords: Authoritarianism; Legitimacy; Religion; Vichy; France.

I am indebted to Mathieu Desan, Ivan Ermakoff, Myra Marx Ferree, Chad Goldberg, Brandon Gorman, Jeff Guhin, katrina quisumbing king, Jared McBride, Laura Nelson, Pam Oliver, Letta Page, Eric Schoon, and Charles Seguin for their helpful feedback on this paper. My gratitude also extends to the archivists in Paris, Lyon, and Cambrai for their assistance in helping me locate documents necessary to telling this story. Funding for this project was received from the Saul Kagan Claims Conference, the Chateaubriand Fellowship from the French Ministry of Foreign Affairs, the Scott-Kloeck Jensen Global Studies Fellowship from UW Madison, several Berman Fellowships and Mazursky Grants from the Center for Jewish Studies at UW Madison, and a "Ouisconsin” Field Research Scholarship. I also benefited from feedback by audiences in the annual conferences of the American Sociological Association (2017) and Social Science History Association (2016, 20 I 7). All errors are my own.

Aliza LuFT, Department of Sociology, University of California, Los Angeles [aluft@soc.ucla.edu].

European Fournal of Sociology, 6 I , I , (2020), pp. 67-I I I(C) European Fournal of Sociology 2020. This is an Open Access article, distributed under the terms of the Creative Commons Attribution licence (http://creativecommons.org/licenses/by/4.o/), which permits unrestricted re-use, distribution, and reproduction in any medium, provided the original work is properly cited. doi: IO. IOI 7/S000397562000004I 
When we think of the 2oth century's big and horrible eventsWorld War I, World War II and the Holocaust, the Cold War and its nightmarish Third World proxy fights—we think of statesmen and business interests and covert operations; we look at major ideological systems like liberalism, communism, and fascism. But we seldom consider religion, and that's a mistake...

(Daniel Denvir on The Dig Podcast, Febrary 2 I, 2020) ${ }^{\mathrm{I}}$

\section{Introduction}

O N 10 J U L Y I 940, the Vichy regime ${ }^{2}$ came to power in France and the French Third Republic was dissolved. Almost immediately thereafter, a new authoritarian government, led by Prime Minister Phillipe Pétain, undertook a massive effort to reorganize French society. The "National Revolution" was central to this effort. Its principles of work, family, and fatherland represented a shift from Republicanism and its civic virtues of liberty, equality, and fraternity to an ethnic nationalism that privileged ancestry, tradition, and religion as if biologically transmitted. ${ }^{3}$ In turn, the regime's first targets were those perceived as “others”, primarily foreigners and Jews, who were considered external to the national, and natural, community. The historian Phillipe Burrin explains how, three days after the armistice was signed on 25 June, "Pétain addressed his compatriots to inform them of the implementation of the armistice and in the very same breath, he announced the beginning of a new order and bade them help him to set up a 'new France'” [i 996: I 4]. This new order was among Pétain's chief priorities, and the exclusion and limitation of "non-French" individuals' rights was central to its philosophy.

Pétain, for his part, never spoke publicly about the "Jewish Problem." He did, however, help to prepare the Statut des $\mathscr{F u i f s}{ }^{4}$, even broadening its initial provisions to increase its severity. ${ }^{5}$ Pétain also regularly spoke in

I Podcast on line [https://www.thedigradio. $\mathrm{com} /$ podcast/catholic-anticommunism-withgiuliana-chamedes/].

${ }^{2}$ For readability, I use the terms "Vichy Regime," "Vichy," "Pétain's regime," "the regime," and "the French State" as synonyms throughout this article. In each instance, I am referring to the authoritarian French government led by Marshal Philippe Pétain during World War II.

3 Ironically, France and Germany epitomize the classic distinction between civic and ethnic nationalism, as neatly laid out in Brubaker's analysis of the immigration policies of both countries [Brubaker I 992]. Hence, I argue that one of the Vichy regime's main goals through its program of National Revolution was to transform France's political culture for thinking about national belonging.

4 The Statut des Fuifs, or Jewish Statute, was the first in a series of anti-Semitic laws promulgated by the Vichy regime to limit the rights of Jews.

${ }_{5}$ Le Statut des Fuifs annoté de la main de Pétain [Retrieved from: http://www. memorialdelashoah.org/index.php/fr/archives-etdocumentations/les-archives/document-inedit-leprojet-de-loi-portant-sur-le-statut-des-juifs]. 
coded discourse, framing Jews as national outsiders, such as when he proclaimed in September I 940 that "true fraternity" in France was "possible only in natural groups such as the family, the ancient towns, [and] the nation" [Marrus and Paxton (I98I) I995: I 7]. ${ }^{6}$ Further, according to several historians [e.g., Adler 200 I; Bédarida I 998; Burrin I 996; Le Moigne 2005; Marrus and Paxton ( I 98 I) I 995; Paxton I 972; Rousso I99I; Vinen 2006; Wieviorka 20I6], as well as the perspective taken here, whether state anti-Semitism was overtly promulgated or covertly advanced, the National Revolution of Pétain's Vichy regime was concomitant with violence against Jews from its very inception. ${ }^{7}$

And yet, despite (or perhaps because of) the crisis of the summer of I 940, it was not a given that Vichy would be able to reorganize French society as it wished. Pétain became Prime Minister of France under vexed circumstances; ${ }^{8}$ to secure his political agenda, the Vichy regime needed to accrue legitimacy. But how?

Research on authoritarian legitimation suggests that rulers seek support through ideological, personalistic, performance-based, and procedural strategies. Yet these strategies and their outcomes are typically isolated to a dyadic relationship between authoritarian rulers and their subjects. Missing from these analyses is attention to meso-level actors who can help or hinder the rise and legitimation of authoritarianism. Defined as institutions, organizations, and leaders who operate in the space between national-level institutions and individuals, this article demonstrates how attention to meso-level actors brings into relief important dynamics about authoritarian legitimation. I examine the French Catholic Church and its shifting relationships with the authoritarian Vichy regime and Jewish community leaders from I 940-I942, and I probe how attention to the middle ground extends existing research on authoritarianism. The results suggest that meso-level actors can facilitate autocrats' efforts to gain support through public endorsements, cooperation, the expression of shared values, and common rhetoric. These

\footnotetext{
6 The original copy of this discourse can be found in Le Temps, 20 September I 940.

7 It is worth noting that an official statement published by the regime the day before the first Statut des fyifs was promulgated (I 7 October I 940) reads as follows: "The government in its task of national reconstruction has, from the very first day, studied the problem of the Jews and of certain foreigners, who, having abused our hospitality, have contributed to a significant degree to that defeat. Although there are some notable exceptions,
}

in the administration and everywhere else, the influence of the Jews has been undeniably corruptive and finally decaying." [As translated in Adler I 987: 16; original document published in Le Temps, I 7 October I940.]

8 A full discussion of the process by which the French government elected to transfer executive, legislative, and constitutional powers to Marshal Pétain is beyond the scope of this project. However, for a useful analysis, see Ermakoff 2008. 
behaviors were all practiced by French bishops during the relevant time period; had that not been the case, as I argue in the discussion, Pétain's ability to carry out the National Revolution would have been impeded. Instead, however, Jews were excluded from the French national community as Church and State became increasingly aligned.

I begin with a review of the literature on authoritarian legitimation, after which I introduce the argument that meso-level actors shape how top-down efforts to accrue legitimacy are perceived and received by civilians, below. I then explain how religious organizations, as a particular kind of meso-level actor, can help or hinder the legitimation of authoritarianism through practices of verbal endorsement, cooperation, the expression of shared values, and common rhetoric. Next, I introduce the case and relevant background, explaining how and why the French episcopate's support for the Vichy regime from I 940-I 942 mattered for the government's efforts to justify its rule and National Revolution, including its violence towards Jews. This section also explains my focus on the first two years of Marshal Pétain's regime and not the entirety of Vichy's tenure (July I 940-August I 944). I then describe the archival materials and methodological approach that allow me to specify how the Church bolstered Vichy, as well as uncover the consequences of these actions for Jews in France. The results of the analysis are presented next, followed by a discussion of the results in light of research on Vichy France and authoritarian legitimation more generally. The conclusion considers the broader implications of this study.

\section{Authoritarian Legitimation}

A recent proliferation of research on authoritarian legitimation marks a departure from the tendency to examine legitimation in democratic contexts [Burnell 2006; Dukalskis and Patane 20I9; Gerschewski 20I3, 20I8; Kailitz 20I3; Krastev 20II; Tannenberg, Bernhard, Gerschewski, Lührmann, and Soest 20I9; Soest and Grauvogel 20I7]. ${ }^{9}$ Crucially, this scholarship emphasizes a distinction between legitimation as the process by which autocracies seek to generate and maintain support and legitimacy as citizens' normative judgments

\footnotetext{
9 Following Steven R. Levitsky and Lucan A. Way, I define authoritarian regimes as those that lack one of the three defining attributes of democracy: (I) free elections, (2) broad protection of civil liberties, and (3) a reasonably
}

level playing field between incumbents and challengers. Concerning the "threshold for unfairness" regarding point (3), see Levitsky and Way 20IO: IO-I 2. 
vis-a-vis a regime [Dukalskis \& Gerschewski 20 I 7; Gerschewski 20I3, 20I8; Soest and Grauvogel 20I7]. ${ }^{\text {IO }}$ In research on authoritarianism, this distinction is especially important: given the repressive nature of autocracies, it is difficult to tease out whether citizens' compliance is premised on conviction rather than coercion or acquiescence. Scholarship on authoritarian legitimation has thus sought to categorize authoritarian rulers' and governments' strategies for gaining support, whether or not such efforts succeed in producing legitimacy. These legitimation strategies are ideological, personalistic, performance-based, and procedural. $^{\text {II }}$

Research on authoritarian legitimation via ideology emphasizes claims concerning the righteousness of a (prospective) social order [Alagappa I 995; Easton I 975; Holbig 20 I 3; Linz 2000]. Authoritarian rulers may mobilize claims about political goals such as building a socialist or communist state, an ethnonationalist or separatist state, a religiousnationalist state or theocracy, or a conservative or modern state to justify their right to rule. The content of the claims may differ, but the purpose is the same: authoritarian rulers who strive to accrue legitimacy based on ideology assert that beliefs and values about how things ought to be justify their ascent to power.

Authoritarian rulers may also strive to justify their domination by referring to qualities inherent in their personhood. Scholars working in this vein draw on Weber's [( I 922) I 978: 2 I 5-2 I6] three types of legitimate authority-specifically, his traditional and charismatic types of authority-to focus on how a leaders' traits are portrayed to procure support for his or her regime [Brownlee 2007; Isaacs 2010]. For example, traditional authority is based on whether the leader can stake a claim to established customs, such as appointment by heredity, to justify her rule [Brownlee 2007]. Charismatic authority rests on claims about a leader's “extraordinary, supernatural, or exceptional qualities,” as evidenced by their previous actions (for example, helping to win a war),

\footnotetext{
10 Following Johannes Gerschewski [20 1 8, ff. I], I define autocracy as an umbrella term that captures different types of authoritarianism (i.e., military dictatorships, single-party regimes, theocracies, monarchies, competitive and electoral authoritarian regimes, and so on). Following Marcus Tannenberg, I define regime as "a set of formal and/or informal rules that govern the choice of political leaders and their exercise of power", and government as "the chief executive along with the cabinet,
}

ministries, and top civil servants" [Tannenberg et al. 20I9: 8]. For legibility, I use the terms authoritarian ruler, leader, and authoritarian government interchangeably, recognizing that in autocracies, these are typically aligned.

${ }^{\text {I I }}$ Of course, different scholars organize authoritarian legitimation strategies differently, resulting in more or fewer categories depending on the criteria at hand. On the legitimation of political power more generally, see Beetham i 99I. 
benevolent paternalism, or a God-given right to rule [Tannenberg et al. 20 I 9: 6].

A third approach concerns authoritarians' performance-based strategies of legitimation. Here, authoritarian rulers assert that they will secure physical, material, and social goods and services for citizens, and legitimacy results if and when they achieve concrete outcomes [Cassani 20 I 7; Dimitrov 2009; Hechter 2009; Soest and Grauvogel 20I7]. This is similar to Easton's [1965, I975] idea of specific support, defined as a "quid pro quo for the fulfilment of demands" [ I $965: 278$ ], and Scharpf's [r 999] theory of output legitimacy, which hinges on whether governments are able to address the issues their citizens care about. Performance-based processes of legitimation first work on promises, then pragmatic strategies for promise fulfilment. In the absence of fulfilment, leaders must successfully identify barriers to that fulfilment-a sort of scapegoating for their failures.

The final strand of scholarship on authoritarian legitimation concerns authoritarian governments' use of procedural practices. Such work draws on Weber's [( I 922) I 978: 2 I 5-2 I 6] third type of legitimate authority: rational-legal authority. Though typically associated with democracies, this tactic is increasingly popular in autocracies, particularly post-Cold War. Examples of procedural practices include establishing the apparent infrastructure of non-authoritarian rule. This may include staging sham or quasi-competitive elections, establishing political parties and legislatures, and/or tasking semi-legal and bureaucratic apparatuses with resolving social conflicts [Gandhi 2008; Gandhi and Lust-Okar 2009; Levitsky and Way 2010; Lee and Zhang 2013; Schedler 2002, 20I3]. In allowing for procedural practices, however insincere, rulers try to satisfy their populations in order to obtain legitimacy [Schedler 20 I3].

Each of these approaches offers powerful explanations for how autocracies strive to generate support. Although my review separates these four strategies to organize extant scholarship, any authoritarian regime is likely to employ several legitimation strategies at once [Alagappa I 995; Cassani 20I7; Dukalskis and Patane 20I9; Weber [(1919) 2004]. Additionally, different kinds of autocracies can start as one type of regime but develop into another, shifting strategies along the way [Levitsky and Way 20 I o; Soest and Grauvogel 20 I 7]. Further, some of these processes are more common in contemporary autocracies (e.g., interest-based legitimation, procedural legitimation) while others (personalistic legitimation, ideological legitimation) were more common in the past [Levitsky and Way 2010; Schedler 2002, 
20I3]. Increasingly, scholars also point to the role of international factors, such as authoritarian regimes' membership in regional organizations or as exporters of ideological or public goods and resources, that can be mobilized to support claims to legitimacy [Burnell and Schlumberger 2010; Schatz 2006; Soest and Grauvogel 20 I 7].

Yet one challenge for scholars of authoritarianism is the tendency in this research to focus solely on authoritarian rulers and their governments while neglecting the meso-level actors who can facilitate or impede autocrats' efforts to gain support. ${ }^{\mathrm{I} 2}$ Defined as institutions, organizations, and their leaders who operate in the space between national-level institutions and individuals [Finkel and Straus 20 I 2], meso-level actors matter for several reasons.

First, although authoritarian rulers may engage in diverse legitimation strategies from above, how civilians interpret these messages depends, in part, on the endorsement of local authorities that they know, trust, or admire. Second, civilians' responses to autocracies will be influenced by whether such meso-level actors join the established government or refuse to join when asked. The issue here is one of cooperation: authoritarian rulers can capitalize on the recognized legitimacy of meso-level actors by establishing close relations with them, convincing them to join their ranks, and so on. Authoritarians can also bolster their legitimacy to the extent that they, too, are allowed to partake in actions typically reserved for leaders or members of the meso-level organization. If meso-level actors deny access to rulers, this can send a powerful message to constituents that the regime itself is unacceptable. Third, meso-level actors can connect the expressed values and beliefs of rulers to the values of constituents by interpreting them in ways that generate support or resistance. If meso-level actors express authoritarian values as their own, this can increase the rulers' perceived legitimacy; an antagonistic stance that disagrees with these expressions will have the opposite effect. Finally, authoritarian rulers can directly deploy cultural frames and schemas by drawing on rhetoric they know will resonate with members of meso-level organizations to justify their rule. However, here, too, it is meso-level actors' responses to these tactics that will shape whether or

\footnotetext{
${ }^{2}$ Meso-level actors are distinct from the ruling elite, who have received significant attention from scholars of authoritarianism [e.g., Blaydes 2010; Brownlee 2007; Kailitz and Stockemer 20I5; Levitsky and Way 2010, 2012; Magaloni 2006, 2008; Reuter
}

and Gandhi 20I I; Reuter and Szakonyi 20I9; Svolik 2009]. While the ruling elite are tied to the regime (e.g., ministers, local officials), meso-level actors are not necessarily connected to the government but can become so, as in the case presented here. 
not authoritarians can do so successfully. ${ }^{13}$ As the focus of this paper is on the Catholic Church in Vichy France, each of these practices is discussed below with reference to religious organizations.

\section{Religious organizations as meso-level actors}

Religious organizations are one example of meso-level actors with power to mediate the relationship between "between center and periphery and elites and masses" in authoritarian contexts [Gorski and TürkmenDervisoglu 20 I 3: 203]. Primarily, this is because religious organizations possess significant influence by virtue of their moral authority [Grzymala-Busse 20I5, 20I6]. Whereas the state makes claims to political authority, religious leaders can transcend the state and its leaders by classifying a regime's policies and practices as virtuous or sinful in the eyes of a supreme being. This "normative ordering power" of religion can in turn help or hinder authoritarian legitimation by tying authoritarians' claims to legitimacy to sacred ideas about "what is" and "what ought to be" beyond partisan interests [Brubaker 20I 5: 5; Geertz I983 in Williams r 996: 370; Grzymala-Busse 2016: I3]. It can also raise the stakes of subversion where authoritarianism is endorsed by religious authorities, or compliance where it is rejected insofar as each position entails countering the will of God.

Religious organizations can also support authoritarian legitimation if their leaders develop cooperative working relationships with authoritarians or take positions in their administrative apparatus. In practice, this means that religious authorities hold office or titles at different levels of government and, in return, the state may support religious education and infrastructure, collect taxes for religious bodies, and pass laws that align with religious values [Phillpot 2007]. This mechanism matters for legitimation because religion is commonly considered a source of communal loyalty. Hence, in joining autocracies' administrations or linking their organizations' fate to the regime, religious organizations and their

\footnotetext{
${ }^{1} 3$ In important respects, the relationship between meso-level actors and authoritarian rulers' strategies of legitimation is akin to the finding in research on organizational forms that authorization or endorsement of important actors external to organizations, including cultural endorsement, helps new social objects acquire popular acceptance [Johnson, Dowd,
}

and Ridgeway 2006]. A key difference, however, is that new institutional research on organizational legitimation processes focuses on how meso-level actors gain acceptance. As a result, it looks to how higher authorities such as the government and equal or lower-ranked actors such as peers and subordinates shape legitimation outcomes. 
followers inevitably become stakeholders in the regime's success. As a result, resisting the regime can mean harming one's own religious community.

To the extent that authoritarian rulers can credibly express the same values as religious authorities, they can also frame themselves as aligned with the fundamental beliefs, concepts, and principles that guide religious organizations. Of course, one way in which credibility is obtained for the expression of shared values relies on whether or not religious authorities mirror these expressions and proclaim these same values as their own. If religious leaders explicitly disagree with rulers' stated values, declare them to be the opposite of their community's belief systems, or if they accuse rulers of being disingenuous or inconsistent through their actions, this can harm authoritarians' attempts to garner support. Hence, whether or not rulers and religious authorities express shared values is yet another way in which legitimation processes can be influenced by meso-level actors.

Relatedly, authoritarian rulers can draw on religious rhetoric including language and symbols to accrue legitimacy, which is then strengthened when supported by religious authorities. Fox [2018] explains, "religious rhetoric is the use of religious language and imagery intended to persuade." But it is not simply that it is intended to persuade that matters, it is also how it persuades: religious language and symbols comprise religious beliefs and values in material form. The practices may be explicitutterance of words and prayers, donning particular habits, using ritual objects, or depicting oneself as an icon-but because their meanings are coded into repetitive actions or emblems rather than overtly stated, their impact can be largely unconscious [Guhin 20 I 6: I 54]. Where politicians and clergy alike frame authoritarians' actions using religious rhetoric, and where religious authorities include rulers in rites and rituals, they can tap into followers' implicit understandings of right and wrong and facilitate the legitimation of authoritarian political arrangements in turn.

Finally, though not the focus of this paper, religious organizations can directly mobilize support or resistance to authoritarianism by supplying followers with ideological justifications for action (or inaction) as well as material resources and social networks. As a wide body of research on social movements shows, religious organizations can provide a physical space for activists to meet and organize, material resources such as newsletters and mailing lists, financial resources, and connections to likeminded peers [McAdam I 982; Morris I 984; Smith I 996; Staggenborg I99I; Zald and McCarthy I987]. In authoritarian contexts where the costs of participation are high, public meeting space is rare, material 
and financial resources are difficult to come by, and identifying trusted others is challenging, religious organizations themselves can be used to organize collective action [e.g., Braun 2016, 20 I 9]. ${ }^{\text {I }}$

Of course, whether or not any of these dynamics is unique to religious organizations as a kind of meso-level actor remains to be determined. Following Brubaker [20 I 5] and Grzymala-Busse [20 I 5, 20 I6], however, I hypothesize that the normative ordering power of religion provides religious organizations with an especially potent form of moral authority. Still, there is no reason that organizations such as trade unions or student groups (to give two examples of meso-level actors that may or may not operate in authoritarian contexts) cannot function similarly. The following section therefore motivates this article's focus on the French Catholic Church in Vichy France and during the Vichy regime's first two years of rule.

\section{Background}

Numerous French historians have noted the important role of various organizations in shaping public opinion through their support for the Vichy regime [e.g., Burrin I996; Sapiro 2014] The historical record, however, suggests that the French Catholic Church had an especially powerful impact on French civilian's responses to the war, defeat, and subsequent settlement around a policy of collaboration with Nazi Germany, including the decision, three weeks after the armistice, to transfer full constitutional powers to Marshal Pétain. Approximately 85\% of France was Catholic in I 940 [Bédarida I 998: 7], and churches were flooded with civilians seeking guidance in the chaos following France's defeat [Drapac I 998: I 42]. Under the new regime, the Catholic Church became a "central player in the drama of public life" [Nord 2003: I I] and Catholicism became "the single most cohesive force in French society after Germany defeated France" [Drapac I 998: 28]. Kselman [2000: 5 I5] explains, "many French who previously had an attenuated relationship with the institutional Church were drawn into Catholic sanctuaries and shrines as a way to deal with the trauma of war and defeat." Jackson [2003: 25] corroborates this assertion, "religion was not an epiphenomenal issue:

\footnotetext{
${ }^{1} 4$ Braun suggests that several of these features are more likely to exist where religious communities are minorities, providing them with a distinct advantage for clandestine mobilization compared with religious majorities
}

[Braun 2016, 2019]. However, the example of Catholic resistance in Vichy France indicates that majority religious organizations are still able to draw on these resources to organize clandestine action, even if the costs are higher. 
Catholic and lay associations had networks of patronage and social organizations extending into almost every crevice of French associational life."

Pétain was well aware of the Church's influence on public opinion and frequently sought guidance from bishops on all matters of policy, including what to do about the Jews [Marrus and Paxton ( I 98 I ) I 995: 202]. The Church responded with praise for the new regime, and it privately lent its support to the Statut des $\mathscr{F u i f s}$ - the first in a series of exclusionary laws that would eventually facilitate the incarceration, forced deportation, and eventual mass murder of approximately 80,000 Jews from France. ${ }^{\text {I } 5}$ This alignment between Church and State was significant to observers, leading one contemporary to remark on Christmas I 942 that "since I 94 I, the man in the street, when talking about Vichy, calls it "the Regime of Clergy." "I6 It is commonly accepted among French historians that in the first two years of its rule, the French Catholic Church underpinned Marshal Pétain's efforts to legitimize his government and sent signals to its followers that it supported the regime's policies and practices.

Following this, the Church's blessing of the regime made resistance more difficult for those who opposed its dictates. This was particularly the case in summer I94 I when Vichy agreed to the Paris Protocols and armed resistance against Germany began in the Occupied Zone. In response, Vichy collaborated with the Nazis in meting out disproportionate punishments: Hitler ordered the execution of 50 French hostages for every German killed and the Vichy authorities hand-selected these hostages themselves. Simultaneously, in Paris, Jews were arrested for the first time by French police in collaboration with German authorities and deported to transit, labor and detention camps throughout the country. These and similar actions led to the creation of Témoignage Chrétien, a clandestine Christian resistance movement formed by lower clergy and laity activists with the aim of disrupting the hierarchy's support for Vichy. In its first edition, Témoignage Chrétien issued a scathing critique of the Church:

${ }^{1} 5$ A full discussion of how and why French bishops decided to support the first Statut des Fuifs is beyond the scope of this paper. For an elaboration on this topic, see Luft 2016, chapter I.

${ }^{16}$ Archives Nationales, $72 \mathrm{AJ} / 73$, Dossier $\mathrm{n}^{\circ} \mathrm{I}$, Résistance chrétienne, I. "Consultation sur quelques cas de conscience posés aux Catholiques de France par l'occupation Allemande." Non signés. s.d. Pièce I. Though unsigned, several sources attribute this document to a Jesuit professor at the Catholic Institute of Paris, Jules Lebreton [Tallett and Atkin I99I]. Importantly, this public support of the Catholic Church for the Vichy regime was not unanimous among bishops and many privately disagreed with this stance. 
In subscribing to the ideals of Travail, Famille, Patrie... the Church has compromised herself by working indirectly in the installation of a new order dictated by Nazis... COLLABORATION WITH THE GOVERNMENT OF THE MARÉCHAL = COLLABORATION WITH THE NEW ORDER $=$ COLLABORATION WITH THE TRIUMPH OF NAZI PRINCIPLES. ${ }^{\text {I }} 7$

From its members' perspectives, the episcopate's alignment with Vichy was unconscionable-yet they were frequently told by their religious leaders that it was "an offense against the Christian spirit" to resist the government "because Catholic morality teaches submission to the legitimate civil power." 8 The Church's support for Vichy thus motivated their clandestine actions, but such actions were risky, to say the least. In addition to the danger of severe punishment by government, participation entailed violating the teachings of the hierarchy, which many Catholics had been trained to obey without question. Hence, given that the episcopate and Vichy were joined together in promoting the National Revolution, which violently discriminated against Jews, participation in resistance required two acts of disobedience: one against the legal government of Vichy, the other against the dictates of the Catholic Church [Bédarida I 998: I 2 I].

Finally, on 23 August I 942, the Archbishop of Toulouse, Cardinal Jules-Géraud Saliège, publicly defected from the episcopate's stance of silence toward state anti-Semitism to protest on behalf of Jews. This sudden shattering of silence to help save Jews in France marked a dramatic change from the committed public support that the episcopate previously provided to the regime. "The Jews cannot be abused without limit," Saliège declared. "They are part of the human species. No Christian dare forget that!" ${ }^{9}$

Following this protest, nine other bishops spoke out on behalf of Jews along with hundreds of lower clergy throughout Vichy France. The protest document was also broadcast for four days on the BBC and Vatican Radio. It even received global media attention. The international Holocaust remembrance organization Yad Vashem describes how, "Overnight, the document became a manifesto; hundreds of thousands of copies were made and were circulated by members of the Resistance

${ }^{17}$ "France, prends garde de perdre ton âme," November I94I, in Bédarida and Bédarida $200 \mathrm{I}: 40-74$, capitalization in the original.]

I 8 Semaine Religieuse de Clermont, 6 September I 94 I, as cited in Bédarida I 998: I 22, ff. Io.

19 Archives diocésaines de Toulouse, Fonds de Mgr. Courrèges, Carton I, Folder I/3. The subject of this protest and those that followed, as well as what motivated bishops to defect from their previous position of support for the regime, is beyond the scope of this paper. The protest, its antecedents and consequences, are the focus of a book manuscript currently in preparation by the author. 
throughout France." ${ }^{20}$ In contrast with their previous positions of support for Vichy, French bishops' now encouraged civil disobedience in response to the ongoing violence against Jews. Moreover, following the bishops' protest, monthly deportation rates collapsed and never again rose to the high level of over 40,000 Jews deported and killed in 1942 [Griffioen and Zeller 2006; Seibel 20 I 6]. Bishops helped to prepare false documents for Jews in need, they offered religious institutions as safe havens for Jews to hide in, and they supported the clandestine efforts of resistance groups such as Amitié Chrétienne, in which Catholics, Protestants, and Jews mobilized to rescue as many Jews, especially Jewish children, as possible. Many who worked with Amitié Chrétienne were active with Témoignage Chrétien, as well. ${ }^{2 \mathrm{I}}$

French historians frequently refer to the bishops' protest as a critical juncture in the trajectory of the Holocaust in France. It transformed public opinion towards Vichy and inflamed Catholics' sympathy for action to help Jews [Laborie 200 I : 282-283]. It can therefore be argued that had French bishops not been supportive of Vichy up to this point, and had they not bolstered the regime's attempts to accrue legitimacy, their protests would have had less of an impact. Instead, it was because the episcopate rallied to the regime in its first two years of rule that their defections in August 1942 mattered.

Subsequently, the bishops' alignment with the Vichy regime for its first two years can be considered a "critical antecedent"-what Slater and Simmons [20 I ०: 889] define as "factors or conditions preceding a critical juncture that combine with causal forces during a critical juncture to produce long-term divergence in outcomes." Without bishops' two years of public support for Vichy and without their silence regarding its antiSemitic policies, the bishops' protests would have caused less of a rupture. In fact, had the episcopate resisted Vichy from the beginning, the Church itself might have been shuttered or attacked, as was clearly the case elsewhere in Europe (e.g., Poland, Austria). After the bishops protested in France, Prime Minister Laval threatened to arrest priests who supported the resistance and to search cloisters for Jews in hiding [Hilberg (I96r) I985: 64r]. Similarly, an official in Toulouse that worked for the Commissioner-General for Jewish Questions called for

\footnotetext{
${ }^{20}$ Yad Vashem World Center for Holocaust Research, Database of Righteous Among the Nations, M.31.2/197, Archbishop JulesGéraud Saliège.

2 Importantly, in addition to Témoignage
}

Chrétien and Amitié Chrétienne, other clandestine efforts by Catholics to protect Jews were underway at the time of the bishops' protest. However, these were small in scale compared to those that followed. 
the punishment of defectors by the nuncio, arguing that bishops had no business protesting because the Church itself counseled obedience to Vichy [Marrus and Paxton (I 98I ) r 995: 20I]. Understanding precisely how bishops supported the Vichy regime in the first two years of its rule thus helps explain what came next, even though that is not the focus of this article.

Rather, this article explains how the authoritarian Vichy regime recruited leaders in the French episcopate as part of its legitimation strategy, and how French bishops responded. I also examine the consequences of these dynamics for the relationship between the State, Church, and Jews. Although the subject of French bishops' support for Vichy has received significant attention in the relevant historiography, this article is specifically concerned with systematically detailing what religious authorities did and their consequences for authoritarian legitimation. The focus is on French bishops' behaviors, recognizing that it was these behaviors that bolstered the government's efforts to accrue legitimacy and civilians' perceptions in response. I analyze shifting relationships between the Vichy government, Catholic authorities, and Jewish religious leaders and demonstrate how meso-level actors contribute to legitimation processes in authoritarian settings.

\section{Data and Methods}

The article draws on a variety of sources on the French Catholic episcopate, the Vichy government, and Jewish leaders and their organizations. Among these are bishops' private diaries; notes and communications between bishops; bishops exchanges with the Papal Nuncio Valerio Valeri; and their correspondence with various representatives of the Vichy government, including Marshal Pétain. I also include sermon notes, mass announcements, local publications that gave voice to the Catholic Church in France during this period, and publications in official diocesan weekly newsletters titled Semaine Religieuse, which were specific to each diocese. ${ }^{22}$

Primary documents from chief rabbis in the French Rabbinate and their meeting minutes and correspondence with Catholic and Vichy authorities are also examined. This data was collected from the diocesan archives in Cambrai, Lyon, Paris and Toulouse, the Centre national des

\footnotetext{
22 Though, importantly, they were often subject to censorship, as with all publications in France from I 940 to I 944 .
} 
archives de l'Église de France, the archives of the Alliance Israélite Universelle, and the French National Archives. All translations are mine unless otherwise noted. Secondary sources are specified in parentheses.

In analyzing these documents, I focus chiefly on processes that involve or indicate shifting patterns of relations among Vichy governmental authorities, the Catholic hierarchy, and Jewish leaders. In other words, I take an explicitly relational approach: rather than examining individuals or groups as entities—whether they be "the Church," "the State," "the Jews," and so on-I focus on the relationships between them, particularly on the dynamics of interactions between religious and political authorities in France. Hence, throughout this paper, I do not seek to understand the characteristics of the Church as an organization nor the Vichy government nor "Jews in France." Rather, I am interested in the changing patterns of relations between religious authorities and political authorities in France during this time period. Pursuing this relational approach to historical analysis allows me to consider the impact of these dynamics for each category of actor as a result of their changing interactions.

\section{Public endorsements}

There was no shortage of public claims of support from Church authorities for the Vichy government, and vice versa. Claims from the Church regularly expressed support for the regime with reference to God as a moral authority that provided for Pétain's leadership and endorsed his rule. Additionally, throughout I 940-I 942 the episcopate issued regular exhortations to the laity to submit to the regime and adhere to its rule. This was so even after summer I 94 I, when the first mass arrests of Jews in Paris by the French police took place and the first stirrings of a specifically religious resistance began to rumble. Best-known among these endorsements is Cardinal Pierre-Marie Gerlier's famous declaration, on I 9 November I 940, that "Pétain is France, and France today is Pétain."23

Importantly, this statement by the official spokesperson of the Church was not representative of all individual beliefs in the episcopate during the summer and prior to the bishops' decisions to support the Statut des Fuifs in late August. However, historians have not been wrong to emphasize the significance of this statement since whatever dissension existed in the Church was kept private. Publicly, the episcopate presented a united front

\footnotetext{
23 Semaine religieuse du diocèse de Lyon, 29 November I 940. For a detailed analysis of this famous speech, see Georges 2003 .
} 
of support for the regime. Hence, when Gerlier openly praised Pétain in front of a crowd of hundreds, the episcopate's position concerning Vichy's legislated anti-Semitism was already established. Adding to his famous sermon, Gerlier declared: "France needed a chief who would lead her to her eternal destiny, God has allowed for you to be here." In the months that followed, Cardinal Emmanuel Suhard in Paris and Monsignor Jean Delay, the Bishop of Marseille, likewise expressed their support for France's new leader, with the latter declaring in his cathedral on 2 December I 940, "God is using you, monsieur le maréchal, to awaken France." ${ }^{24}$ Such religious public endorsements contributed to the regime's efforts to legitimize itself by framing Pétain's rule as divinely sanctioned.

To dispel concerns that these words of praise might have been naive and confined only to the beginnings of Pétain's reign, one need only to look at similar declarations of support for the Vichy government throughout I94I. In the Association of Cardinals and Archbishops (ACA) meeting of I 5 January I94I, bishops in the Occupied Zone professed their "total loyalty to the state and the government in France." ${ }^{25}$ This position was endorsed by the ACA in Unoccupied France two weeks later. ${ }^{26}$ On 4 May I94I, Bishop Gabriel Piguet of Clermont-Ferrand claimed, "[Pétain] alleviates our misery and seeks to eradicate, through... himself and his glory of yesteryear, the costs of our misery." 27 Repeatedly, bishops in the episcopate throughout France declared Pétain a legitimate ruler and urged their followers to rally around him and his regime.

Yet, simultaneously, Jews were losing their right to work and being stripped of their ability to claim allegiance to France and her government. Already on 22 July I 940, the Vichy regime had set up a Commission for the Revision of Naturalizations to review all grants of French Citizenship since I 927 . Jews were disproportionately affected by these proceedings: while roughly i 5,000 men, women, and children were denaturalized, approximately 7,000 of them were Jewish. The goal was to eradicate the "anti-France"-supposed internal enemies including Communists and freemasons in addition to immigrants and Jews, many of whom were recently arrived immigrants, as well [Zalc 20 I6].

\footnotetext{
${ }^{24}$ L'Écho de Notre-Dame-de-la-Garde, I 4 December I 940.

${ }_{25}$ Archives diocésaines de Cambrai, fonds Chollet, I B. 24; Procès-verbal de l'Assemblée des Cardinaux et Archevêques de France, Paris, I 5 January I 94I.
}

\footnotetext{
${ }^{26}$ Archives diocésaines de Cambrai, fonds Chollet, I B. 24; Conférence épiscopales de Lyon, 5-6 February I 94 I.

${ }^{27}$ La Croix d'Auvergne, 4 May I 94I.
} 
Then in July I 94 I, one month after the first major roundup of Jews in Paris had occurred, the ACA in the occupied zone (but with Gerlier in attendance) proclaimed the regime legitimate and called for "a sincere and complete loyalty to the established power. We venerate the head of state and urge the union of all French around him." 28 Their statement exhorted Catholics to remain loyal "without enthrallment to the public order," a phrase several historians have highlighted as evidence of a request for moderation by French bishops [e.g., Clément I 999]. Others have critiqued this assessment, arguing, first, that this message was so subtle it could hardly be construed as a meaningful tempering by the episcopate vis-à-vis the government's anti-Semitic policies and, second, that it did not even stop bishops from continuing to publicly revere the government [Fouilloux 2002]. ${ }^{29}$ As Jackson [2003: 268] explains, "in practice the qualification 'without enthrallment' did not prevent delirious effusions of devotion to Pétain from individual prelates" throughout the summer and onwards.

Prominent declarations of support for the state from the Church were even evident as late as I September I 94I, just two weeks after 4,232 French and foreign Jews were arrested in Paris by French municipal police along with German Feldgendarmes ${ }^{30}$ and taken to the Drancy internment camp. Located northeast of the city, Jews were frequently detained in Drancy during the war prior to their deportations to Auschwitz. On the day of this rafle or roundup, the secretary of the Catholic episcopate, Monsignor Jean Chollet, beseeched the faithful to follow the Marshal's plan for France:

We have no right to criticize the leader himself or his orders. The subordinate obeys without question or inquiry $[\ldots]$ in the name of our own religious conscious we will be the most united and the most disciplined of citizens. ${ }^{3 \mathrm{I}}$

One month later, in October I 94I, synagogues in Paris, Marseille, and Vichy were attacked and destroyed. In response, the Council of the Association of French Rabbis adopted a declaration for Chief Rabbi Isaïe Schwartz to transmit to Cardinal Gerlier. ${ }^{32}$ The document describes the council's anguish and desperation for some kind of public support from

${ }^{28}$ Archives diocésaines de Cambrai, fonds Chollet, I B. 26; Procès-verbal de l'Assemblée des Cardinaux et Archevêques de France, Paris, 24-25 July I 94I.

${ }_{29}$ Fouilloux's critique does not stop there: she accuses Clément of bias and seeking to minimize the content and scope of the bishops' support for the regime more generally. It is not surprising, then, that Clément is among those who consider the phrase "without enthrallment" as evidence of the bishops' moderation.

30 The Feldgendarmerie was a German military police unit that operated in Occupied France during the Holocaust.

${ }^{3 \mathrm{I}}$ Cited in Pury 1 978: $3 \mathrm{I}$.

${ }^{32}$ Archives de l'Archdiocèse de Lyon, fonds Gerlier. Interventions de Cardinal en Faveur de Divers Fuifs, I 940-I 943, 26 November, I 94I . 
non-Jewish religious authorities. The rabbis wrote: "As with human victims, the stones, sanctified by piety; the tabernacles, that cover our sacred scrolls; we... are anguished. When will this sacrilegious fury end?" 33 They concluded with a plea to their "colleagues who stand on guard around the Lord's sanctuary" ${ }^{4}$ :

How comforting for us and for our anguished brothers it would be if we were to hear our sentiments echoed [...] invoked in the synagogues, the churches, the mosques, and if the faithful of other religions and their spiritual leaders showed their reprobation of these ungodly crimes? ${ }^{35}$

At the end of the letter, the president of the rabbinical council asked all in attendance to communicate this message to ecclesiastical authorities in their communities. ${ }^{36}$ Gerlier, in response to Schwartz, expressed compassion for the rabbis' plight and promised to share the letter with the $\mathrm{ACA}$ in the free zone during his next meeting with the hierarchy. ${ }^{37} \mathrm{It}$ is clear in Gerlier's reply that he was beginning to feel anxious about the Church's silence concerning Jews. However, at this time, Gerlier declined to make a public declaration on their behalf. ${ }^{3}$ In fact, at no time from summer I940 until March I94I did the episcopate even express its concerns about Vichy's anti-Semitic policies and its consequences to the government; a public statement would not be issued until August I 942. When compared with Autumn I 933, when Jewish buildings were first ransacked and numerous bishops spoke out on behalf of Jews in their communities, the shift in relations is glaring [Luft 20I6, chapter I; Bernay 201 2: 64-66]. The tide had turned: no longer could Jewish community leaders expect bishops to publicly unite with them. Instead, all public declarations of support-at least until August I 942would be reserved for the Vichy government.

\section{Cooperation}

In addition to public endorsements, another way in which the relationship between Vichy and the episcopate changed, the latter legitimizing

\footnotetext{
33 Ibid.

34 Ibid.

35 Ibid.

${ }^{36}$ Of note, this was not the only letter the Cardinal received in December I 94 I requesting that he speak on behalf of Jews. In addition to the correspondence and a meeting with Helbronner, Gerlier received a letter from P. Dillard on I2 December I94 I asking that an official letter from the Church on racism
}

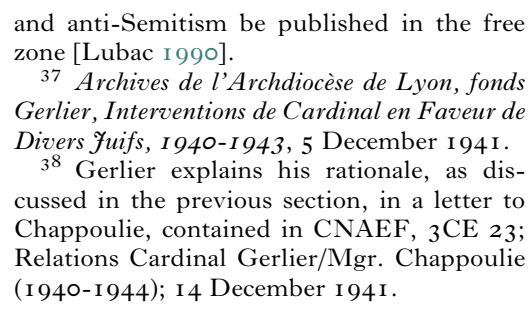

37 Archives de l'Archdiocèse de Lyon, fonds Gerlier, Interventions de Cardinal en Faveur de Divers Fuifs, I 940-I 943, 5 December I 94 I.

${ }^{8}$ Gerlier explains his rationale, as discussed in the previous section, in a letter to Chappoulie, contained in $\mathrm{CNAEF},{ }_{3} \mathrm{CE} 23$; Relations Cardinal Gerlier/Mgr. Chappoulie ( I 940-I 944); I 4 December I 94I. 
the former, is through the incorporation of religious officials and notable Catholics into the structural machinery of the state. Once the new regime consolidated its power, the Vatican officially appointed Archbishop Valerio Valeri to serve as the Papal Nuncio to Vichy. In return, Vichy France appointed its own ambassador, Léon Bérard, to serve as its representative to the Holy See. This confirmation of official positions validated the new regime, as did the introduction of over 200 clerics into communal leadership positions and departmental committees throughout France [Jackson 2003: 268]. In the highest levels of government, prominent Catholics came to serve in powerful roles. ${ }^{39}$ Fouilloux [1 997: I 94-I96] notes that this was the first time since I 879 that so many Catholics had been appointed to high government office. ${ }^{40}$ In contrast, once the first Statut des Fuifs was passed, the state council was purged of all Jews that had previously held a seat [Poznanski 200 I: 43]. ${ }^{4 \mathrm{I}}$

Additionally, in a telling series of letters between Cardinal Gerlier of Lyon and Archbishop Valeri in late February I 94 I, the Cardinal considered whether to accept an offer from Joseph Barthélemy, Vichy's Minister of Justice, to serve on the council of ministers as an advisor. ${ }^{42}$ Gerlier ultimately declined the invitation, but not because of any hesitation over whether the Church should partake in political affairs. In fact, Gerlier even offered the name of a bishop who might serve in his place, the Archbishop of Cambrai and Secretary of the ACA, Émile-Maurice Guerry. ${ }^{43}$ Jackson [2003: 268] summarizes this aspect of the Catholic religious and French political relationship neatly: "prelates were present on most official occasions and bishops were frequent guests at Pétain's table." Rather quickly, the Vichy government was able to bolster its legitimation attempts by embedding religious authorities into the state's administrative apparatus.

\footnotetext{
39 For example, devout Catholics in the Vichy government included General Maxime Weygand, Minister of Defense; Raphaël Alibert, Minister of Justice (until January I94I); Pierre Caziot (Minister of Agriculture until April I 942); and André Lavagne, Pétain's Chef de Cabinet. The first four ministers of education were also religious Catholics, especially the last of this group, Jacques Chevalier (who was replaced by the more moderate Carcopino in February I 94I), as was Xavier Vallat, Commissioner-General for Jewish Questions until May I 942.

40 These officials were not members of the French episcopate. However, efforts were
}

made from I940-I942 to incorporate the higher clergy into the political administration.

${ }^{4 \mathrm{I}}$ However, as Poznanski notes, a few were able to obtain exemptions at first [Poznanski 200I: 43]. However, with the passing of the second Statut des Fuifs in June I 94 I, all public officials would lose their jobs with no exceptions.

${ }^{42}$ Archives de l'Archdiocèse de Lyon, fonds Gerlier, Correspondence Cardinal Gerlier avec La Nonciature, 4 February I 94 I ; 26 February I 94 I; 28 February I 94 I.

43 Ibid., 4 February I 94I. 
Similarly, in Occupied France, Suhard, who had already been nominated to the national council in January, ${ }^{44}$ would eventually decline the nomination in March $194 \mathrm{I}^{45}$, but not without sending his chief aide, Monsignor Roger Beaussart, in his stead. A devoted collaborationist, ${ }^{46}$ Beaussart represented Suhard at the formal welcoming reception when Hermann Göring visited Paris in December [Burrin I 996: 22 I ]. In the same month, Cardinal Suhard assured German Ambassador Otto Abetz that "the clergy is fully disposed to make its influence felt in favor of collaboration." 47

By contrast, during the same period, French rabbinical authorities unsuccessfully sought to affirm their pre-war relationships with Catholic authorities by solidifying institutional alliances. In October I 940, Rabbi Julian Weill called on Cardinal Suhard with the hope of joining both religious organizations together in solidarity — as had been the case before the German invasion-and against what Weill perceived as German pressures that could strike them both. ${ }^{48}$ Less than a decade earlier, the Grand Rabbi Israël Levi invited all Christians to form a "front of defense for the bible," and bishops from France's largest cities, including Paris, Nice, Marseille, and Toulouse, responded, while those in Lyon, Bordeaux, Lille, and Tours sent ecclesiastics as representatives [Bernay 20 I 2: 64-66]. Cardinal Suhard, who was previously the Archbishop of Reims, followed France and Britain's declaration of war with Germany in September 1939 with a letter to his congregation that explained:

Many times, following the sovereign Pope Pie XI, we exposed to you Hitler's racist doctrines [...] we have seen how, in these last few years, this doctrine has imposed destruction and terror [...] we know, along with our allies, that we are defending not only ourselves but all that exists in the world of human value and true Christian values. ${ }^{49}$

Prior to the start of the war, many French bishops publicly and privately aligned with rabbis against Hitler's Nazi ideology in a shared commitment to resist it. Yet all this changed following France's defeat by Germany.

To be sure, Suhard initially expressed in his diary how concerned and disturbed he felt by all that was unfolding around him and he also described

\footnotetext{
${ }^{44}$ Archives historiques de l'Archevêché de Paris, fonds Suhard, ID I4 I8. Fournal Suhard, January I 5-27: 59. Hereafter, I refer to this source as "Suhard's Diary."

45 Regarding his decision to decline the nomination, Suhard details how he told Pétain that he had "great confidence in him" and would "love" to join the national council, but he worried that doing so would "reduce his influence in religious affairs to $80 \%$ ". He felt he
}

would better serve the Marshal by staying “on the religious plan." [Suhard's Diary: 6I ].

$4^{6}$ On November I 94 I, Beaussart stated, "Collaboration [is] the only reasonable course for France and for the Church."

47 Archives Nationales, 3 W 347, Télégramme I496, Abetz à Ribbentrop, I 3 December I 94I. ${ }_{48}^{8}$ Suhard's Diary: 48 .

49 Archives diocésaines de Cambrai, fonds Guerry, 6D 048; also in Guerry I 947: 7 . 
feeling uncomfortable with collaboration, but he rapidly overcame this discomfort and was confident by as early as mid-September I 940 that making common cause with the Germans would bolster the Church. ${ }^{5}$ In an entry recorded between 16 and I 9 September I 940, Suhard wrote:

The occupying power proves correct, and even very correct, with me. What will it be tomorrow? I think the Catholic Church can emerge from this ordeal magnified and glorified by the position she held during this ordeal. ${ }^{5 \mathrm{I}}$

Subsequently, when Rabbi Weill met with Cardinal Suhard in Paris two weeks later, Weill expressed his concerns about rising anti-Semitism and his desire for the Church and the rabbinate to continue fighting Nazism together. However, Suhard had no interest in working alongside him. Suhard was already convinced the Church could benefit from its alliance with the Nazi occupation authorities. Weill was playing a fool's game.

As for the benefits the Church received from the State, perhaps no single issue was of greater importance to the Catholic hierarchy than the republic's institutionalized secularism of state education. Within the first month after the armistice was signed, Bishops Gerlier, Suhard, and Achille Liénart in Lille had met twice to prepare a list of demands from the Church to Pétain, a list that was headed by the issue of Catholic education. ${ }^{52}$ The regime addressed this priority early on: in a famous editorial dated I 5 August I940, the Marshal explained that France's national regeneration would hinge on improving youth education. ${ }^{53}$ Pétain wrote that he anticipated re-introducing France's traditional values of "god, work, and family" into state schools. ${ }^{54}$ In the fall of I 940, General Weygand declared that "France deserved her defeat; she was beaten because her governments for half a century have chased god from school" [Duquesne I 966: 27]. Putting words into action, on 3 September I940, the Vichy government rescinded the I90 I Law on

\footnotetext{
$5^{\circ}$ Importantly, Suhard was arrested by the Gestapo and sequestered in his kitchen for two days on 26 and 27 July I 940, while Cardinal Liénart in Lille and Cardinal Rocques, in Rennes, were arrested and interrogated in late July as well. A full discussion of these arrests and their consequences for bishop's strategies vis-a-vis the Nazis is beyond the scope of this article, but see Luft 20 I 6: 39-42 for a detailed analysis.

${ }^{1}$ Suhard's Diary: 45.
}

\footnotetext{
${ }^{2}$ Archives diocésaines de Cambrai, fonds Guerry 2B 54 I I34, "Note remise [à Vichy] au nom de Cardinal Suhard, Baudrillart, et Gerlier remis à Paris le Io Juliet I 940 et résumant les désirs unanimes de l'Assemblée des Cardinal et Archevêques de France."

53 P. Pétain, "L'éducation Nationales," in La Revue des Deux Mondes, I 5 August, I 940: 350-353. Published in Barbas I 989. 54 Ibid.
} 
Associations that had banned religious orders from teaching. ${ }^{55}$ In October, the écoles normales were abolished, and Suhard remarked in his diary how pleased he was about the changing laws on education. ${ }^{56}$ In December, a law was passed that instructed "duties toward God" to be taught in public schools. ${ }^{57}$ From its very beginnings, Vichy was prepared to work with the Church in a mutual relationship, increasing bishops' willingness to send prelates to political affairs and to ally with Pétain's regime at the highest levels of government.

\section{Shared values}

A third finding to emerge from the analysis is how the Vichy government sought to accrue legitimacy by framing its philosophy and its practices as aligned with Catholic values. Bishops responded in kind, not only in expressing common beliefs about what was desirable but also in identifying shared perceived threats. For example, on I9 November I940, Cardinal Gerlier declared in his famous speech, "Work, family, fatherland-these words are ours." ${ }^{8}$ A month later, Gerlier praised Pétain's National Revolution philosophy in the Fournal des Débats, a French weekly, stating: "The Marshal said one day: 'our fatherland must recover the beauty of its roots.' What is then the most beautiful of all the roots if not Christianity, which gave it birth?" 59 In so doing, Gerlier echoed not only Pétain's speeches but also the Marshal's essays that described a worldview in which Jews were not a part of the natural French community.

Similarly, many in the hierarchy were also quick to express how the Church shared ideological enemies with the Vichy regime [Bartov I 998; Burrin I996; Jackson 2003]. Not least among these was the laïcité or secularity of the past. In September I 940, Monsignor Florent Du Bois de Villerabel, Archbishop of Aix, described the old republic's secularism as a "cancer" that had disfigured France. ${ }^{60}$ The Bishop of Viviers, Monsignor Alfred Couderc, similarly exclaimed that among all the reasons for France's defeat, the greatest, perhaps, was the former republic's "official ignorance of religion." ${ }^{\mathrm{I}}$ A belief that God was punishing

55 Vie sociale de l'Église: Documents et actes officiels: années I 940-I942, I 942 (Paris, Maison de la Bonne presse: $5 \mathrm{I}$ ).

${ }^{5}$ Suhard's Diary: 47.

57 Vie sociale de l'Église: Documents et actes officiels: Années I 940-1942, 1942 (Paris, Maison de la Bonne presse: 54 ).

$5^{8}$ Semaine religieuse du diocèse de Lyon, 29 November I 940.
59 "Dans un vibrant discours, Mgr. Gerlier engage tous les Français à s'unir autour du Maréchal." Fournal des Débats, 28 December I 940.

${ }^{60}$ Semaine Religieuse de I'Archdiocèse d'Aix, I 5 September I 940, 37: 37.

${ }^{6}$ Semaine Religieuse de l'Archdiocèse de Viviers, 28 February I 94 I, 9: 78. 
France for her abandonment of Christian values dominated many bishops' speeches and appeared regularly in La Croix — "the semi-official organ of [French] Catholicism" [Halls I 995: I 70]:

La Croix offered readers a full menu of dissipating factors that had helped lead La Belle France down the road to perdition. These included the obvious Catholic complains of laïcité and dénatalité, as well as an unsparing critique of "Modernism's other errors," from women's liberation to rural flight, as well as the overconsumption of alcohol [Crane 2004: 5 I-52].

The message could not be clearer: Catholics must wholeheartedly support Pétain who promised to reverse the trends that the Church blamed for France's ruin. Redemption for past sins could only be achieved by establishing a political system that promised to reverse them.

Significantly, not only did Catholic authorities encourage the laity to support the government due to their shared values and common enemies; the Vichy government also regularly articulated that it shared this worldview by chastising France for her moral decline and calling for a return to the social values of the Church. For example, a lengthy memo on Church-State relations authored by Pierre Sauret, the Director of Religions and Associations at the Ministry of the Interior, argued it was necessary for the state to work with the Church in rebuilding France, because an absence or abandonment of spiritual values had been an important factor in her defeat. ${ }^{62}$ In addition, although Pétain himself was not religious, he regularly spoke of the need for self-chastisementanother value of the Catholic Church.

Other indicators of conflation between the Church and Vichy's stated values include the many statements made by Church authorities in fall I 940 and throughout I 94 I, expressing their agreement with State officials that there was a "Jewish Problem" that needed to be solved. Political leaders would then use the Church's support as well as their rationale to justify their anti-Semitic policies. For example, when the government asked the episcopate to determine the permissibility of the Statut des Fuifs, the episcopate decided to endorse the law, arguing that Jews were "not your ordinary foreigner welcomed in a country, but an unassimilable one."63 On 25 October I940, three weeks after the Statut was promulgated, Baudouin parroted this rationale in response to a group of American newsmen: "we have decided to limit the action of a spiritual community that, whatever its qualities, has always remained outside the

\footnotetext{
${ }^{62}$ CNAEF, 3 CE $3 \mathrm{I}$, Relations de Mgr. Chappoulie aver Monsieur B. Ménétrel, secrétaire particulier du maréchal Pétain.
}

${ }^{6}$ Archives de diocèse de Cambrai, fonds Chollet, 2B. 47, Procès-Verbal de la Conférence épiscopale de Lyon, 3 I August I 940. 
French intellectual community... [no longer could the Jews] constitute an empire within an empire." 64 The modern "soundbite" was on display.

Later, as persecution against Jews in France intensified, Gerlier would remind ministers in the Vichy government of the episcopate's position toward Jews. In October I 94I, while approximately 8,000 Jews were suffering in concentration camps throughout France, Gerlier told the Commissioner General for Jewish Questions, Xavier Vallat, that the "law is not unjust... but it lacks justice and charity in its enforcement."65 According to Marrus and Paxton [( I98I) I 995: 200], Vallat also reported that Gerlier had told him, "the Jewish problem exists [...] it is indeed inescapable, and I approve [of the anti-Jewish measures] within the framework of justice and freedom." Thus even when religious authorities were becoming concerned by state anti-Semitism, ${ }^{66}$ they still maintained that they were ideologically aligned with the belief that there was a Jewish problem. In other words, the issue was how to address the "Jewish Problem," not whether it existed. ${ }^{67}$

This harmonization of the episcopate and the state's worldviews is striking given the repeated attempts by Jewish leaders to establish an alliance with the Church by highlighting their presumed-to-be-common values. For example, after the first Statut des Fuifs was passed, on 22 October, Rabbi Schwartz denounced the new laws in both occupied and unoccupied France in a letter to Pétain, writing with fervor that they were a form of "racial legislation, [with] principles born outside our borders, repudiated by Judaism, denied by consciousness and sentenced ex cathedra by the head of the Catholic Church and other Christian

\footnotetext{
6425 October I 940. "M. Paul Baudouin Commente Les Mesures Prises à l'Egard des fuifs," Journal des débats politiques et littéraires [http://gallica.bnf.fr/ark:/ I 2 I $48 /$

bpt6k 50985 I 2.langEN, Accessed: ro October 20I4].

${ }_{65}$ Cited in Marrus and Paxton [( I98I) I 995: 200]; Centre de Documentation Juive Contemporaine: CIX-Io6.

66 This concern was privately first expressed after the roundups of summer I 94I, after the second Statut was passed, and after the destruction of synagogues in Paris, Marseille, and Vichy.

${ }^{67}$ In Gerlier's private collections, there is a letter from i 6 July i 94I addressed to "Mon
}

cher deputé." In it Pierre Masse, a former senator, jurist, and cabinet minister who was Jewish, requests the reader to recognize "there is no 'Jewish Question' in France.” He blames propaganda for promoting ideas of Jews as inherently different and internally threatening. Masse concludes "there is no 'solution' for [the Jews] other than to return to them their common rights... any other solution is persecution." Archives de l'Archdiocèse de Lyon, fonds Gerlier, Interventions de Cardinal en Faveur de Divers fuifs, I 940-I 943. I6 July I 941. On 30 September I 942, Masse was deported to Auschwitz and gassed upon arrival [Klarsfeld I 983: 326]. 
churches."68 Rabbi Weill followed suit one day later. ${ }^{69}$ Here, both Schwartz and Weill were referencing Pope Pius XI's I 937 encyclical, Mit Brennender Sorge ("With Burning Concern"), which explicitly condemned Nazi racist ideology. ${ }^{70}$ That the rabbis could write such letters indicates how misguided they were on the Church's "new" worldview. Rabbis Schwartz and Weill tried to appeal to Catholic values to sway the Marshal's stance. Sadly, their letters instead revealed a growing schism between the episcopate with the rabbinate: neither rabbi knew the statute had been passed with the justification of the Catholic authorities.

In a later attempt to remind the Church of their religions' shared values, Rabbi Schwartz's October I94 I letter to Gerlier included a comparison between attacks on synagogues in France and the ruins of Galilee, where Jesus prayed and preached. ${ }^{7 \mathrm{I}}$ According to scripture, Galilee was destroyed by the Romans during the Great Revolt. In referencing this site, Schwartz aimed to remind Gerlier of the customary and ancient connection between Catholics and Jews. Gerlier, in response, sought to comfort Schwartz. However, given that Gerlier told Vallat in the same month that he agreed on the existence of a "Jewish Problem," this comfort could only go so far.

\section{Rhetoric}

Last but not least, the change in how religious and political authorities related to each other in France from I 940 to 1942 was manifest in the discourse and symbols commonly expressed or displayed by both. This shared rhetoric between Church and State contributed to the regime's legitimation process from I 940-I 942 nowhere perhaps more profoundly than with Pétain's classification as a savior. The Marshal identified himself with Christ's sacrifice and regularly framed his leadership position as that of a redeemer, prepared to deliver France from her sinful past into a glorious present and future. Remarking on how Pétain used religious symbolism to establish his authority and attract the support of the Church, Le Moigne [2005: 92] explains:

\footnotetext{
${ }^{68}$ Archives de Consistoire israélite de France, fonds Moch, bobine 3, Correspondence between Jacques Helbronner and Isaïe Schwartz, Letter of protest from the Grand Rabbi of France to Maréchal Pétain. 22 October I 940.

69 Ibid., letter from the Grand Rabbi of Paris, Julian Weill, to Maréchal Pétain. 23 October I 940.
}

${ }^{70}$ Mit Brennender Sorge. "Encyclical of Pope Pius XI On the Church and the German Reich, to the venerable brethren, the Archbishops and Bishops of Germany and other ordinaries, in peace and communion with the Apostolic See,” I 4 March I 937.

${ }^{71}$ Archives de l'Archdiocèse de Lyon, fonds Gerlier, Interventions de Cardinal en Faveur de Divers fuifs, I 940-I 943, 26 November I 94I. 
In his own manner, Pétain could also be considered as the first bishop of the nation, who built his "acceptance speech" on a personal identification with Christ's sacrifice $[. .$.$] This appeal was understood by the Catholic hierarchy.$

It was not only understood by them, however; rather, bishops actively endorsed this personalistic strategy, bolstering Pétain's attempts to legitimize his rule by making charismatic claims.

Hence, in a radio message to the French people three days after signing the armistice with Germany, Pétain declared that he was prepared to give France "the gift of my person." Gerlier, welcoming Pétain to Lyon, exclaimed, "France needed a chief who would lead her to her eternal destiny. God has allowed for you to be here." ${ }^{72}$ Nearly one year later, on I 2 August I 94 I, the Marshal declared to the French people, "In I 940, I put an end to the rout. Today, it is from yourselves that I wish to save you."73 On 3 November I 94 I, Cardinal Suhard in Paris sent a letter to Pétain in which he wrote of his "profound conviction, that God in your person, will always protect France and renew her."74 In December, during Christmas Mass in Notre Dame Cathedral, Suhard similarly spoke of the present as a "time of joy and hope" despite suffering; a time of "salvation," brought to France by a "unique savior." He then turned to extend his Christmas greetings-in front of a crowd of hundreds-to Pétain. ${ }^{75}$

This "Pétain as savior" symbolism was profound. However, it was also through the co-optation of religious symbols that the Vichy regime attempted to legitimize its authority. For example, the regime frequently adopted religious emblems in calling for the public to support its political agenda. One such figure was Joan of Arc, often enlisted to propagate antiBritish, anti-Republican, and even anti-Semitic national values. Pinto [20 I 2: I 8] describes a propaganda poster used by the Vichy government that borrowed vocabulary and imagery from Joan of Arc to make a direct connection between her image and Pétain's. In the poster, Pétain is seen in the likeness of Joan of Arc and is described as fighting a "crusade" against "the Bolshevik peril." The poster links contemporary France to religious crusaders of the past, solidifying the connection between Vichy France and the Catholic Church while at the same time promoting anti-Semitism.

\footnotetext{
72 Semaine religieuse du diocèse de Lyon, 29 November I 940.

${ }^{73}$ New York Times, "Marshal Pétain's address to the French People," I 3 August I 94I.

${ }^{7} \mathrm{CNAEF},{ }_{3} \mathrm{CE} 22$, Voyages de Cardinal
}

Suhard archevêque de Paris à Vichy (I94II943), Letter from Suhard to Pétain, 3 November I 94I.

75 Semaine religieuse du Paris, Io January 1942 . 
Likewise, a propagandist stained-glass window in Orléans showed an image of Joan of Arc alongside an image of Orléans aux Fuifs. The latter depicts Jews dominating French civil society - the army, the legal professions, and parliament—stating that, "[the Jews] wrote the first page in the decadence of our history." The Joan of Arc window, in contrast, "proclaims that the figure that would embody France would be the one who would rid the country of foreigners such as the English and, especially, the Jews" [ibid.: I6-I 7]. Frequent comparisons between Joan of Arc and Pétain were to be heard on Vichy radio, as well. For example, in May I 94I, on the 5 Ioth anniversary of Joan of Arc's death, a broadcast described Pétain as being "cast (like Joan of Arc) in the role to lead France" [Drapac I 998: 265]. The use of Joan of Arc as both religious and national symbolism was but one of the ways in which the state co-opted religious emblems to legitimize its goals.

Yet another was the incorporation of religious rituals into the Vichy regime's ceremonies, and Pétain's frequent attendance at religious services throughout the country. When he attended these services, religious authorities often included him in practices typically reserved for their followers. For example, when Pétain went on his tour of the south of France in November I 940, his visit to the Cathedral of Notre-Damede-l'Assomption in Clermont-Ferrand (Puy-de-Dôme) included a service in which he walked "like a youth" up the steps of the stage, decorated with a simple military medal and matched by none other than the bishop, Monsignor G. Piguet, who likewise wore a military medal and the Croix de Guerre [Le Moigne 2005: 96].

The Church also regularly prayed for Pétain and even wrote new songs of worship that were then taught to followers. In Le Puy, the prayer for Pétain read:

Glorious leader of our country,

Father great of heart, we love you,

Your children's soul has been shattered,

Yet only command, and we will follow you. ${ }^{76}$

There was also the "prayer to Le Maréchal" that the Vichy government itself exhorted the public to declare-a twist on the Catholic "Our Father" that ended with the injunction, "and deliver us from evil, oh Marshal!" Though not a prayer, at the small church outside Vichy where

${ }^{76}$ Cited by Halls, in Tallet and Atkin I99 I: I69. 
Pétain attended mass, children had to sing the "unofficial" national anthem of Vichy, Maréchal nous voila:

In front of you, the savior of France,

We swear-we, your boys-,

To serve and follow in your steps.

Marshal, here we are!

You gave us hope again,

The fatherland will be reborn!

By contrast, Grand Rabbi Isaïe Schwartz was excluded from an official ceremony for those killed in the war between 1939 and I 940, and patriotic commemorations of I 4 July I 940 that took place in the Vichy synagogue were shunned by Vichy government representatives. No one would pray for Jews, and Jewish authorities were not allowed to partake in joint political and religious ceremonies. There was no common rhetoric for Jews and the Vichy government; Jews were excluded entirely.

\section{Discussion and Conclusion}

This article examines how meso-level actors shape authoritarian legitimation processes by examining the case of the Catholic Church in Vichy France during the first two years of Marshal Pétain's rule. Research on authoritarian legitimation identifies four strategies-ideological, personalistic, performance-based, and procedural-that authoritarian leaders and their governments pursue to gain support. Each of these strategies was present in France from I 940-I 942: Chief of State Marshal Pétain declared within the first few days of signing the armistice that his goal was to reorganize French society according to his National Revolution philosophy. This included targeting perceived "others" such as foreigners and Jews whom he considered external to the national (and natural) French community. Pétain also made frequent claims to himself as a savior, characterizing himself as a Christ-like figure, willing and able to save France from what would otherwise be her downfall. He also sought to secure French civilians' physical security by negotiating with Nazi Germany once it was clear, from his perspective, that continuing to fight would lead to the destruction of the country. ${ }^{77}$ The regime likewise

77 Charles de Gaulle, of course, disagreed. 
sought to develop a "planned economy" that emphasized a strong state role in modernizing production as well as a corporatist economic structure to resolve class conflict-though the practical demands of German occupation authorities led to its spectacular failure. Procedurally, Pétain was democratically voted into office through the vexed process of "collective abdication" but, once this occurred, he obtained full constitutional authority [Ermakoff 2008].

From the perspective of the literature on authoritarian legitimation, the presence of these tactics is sufficient to explain the rise of the authoritarian Vichy regime. Yet this article, while recognizing these tactics were necessary, argues they were not, in fact, sufficient. In order to succeed, they required support from meso-level actors, in particular the French Catholic Church, as the Church gained overwhelming significance for shaping public opinion in the crisis and chaos following France's defeat by Germany. In Vichy France, the Church bolstered Pétain's claims to rule through four practices, each with a concomitant impact on the hierarchy's relationship with the rabbinate. This suggests that had the Church made different decisions during this time period, Vichy's trajectory might have been quite different, including of course in its consequences for Jews.

For example, concerning the first practice, public endorsements, while bishops publicly praised Pétain and encouraged the laity's loyalty to the regime, Jews were being stripped of their right to work, stripped of their citizenship, and arrested and detained in concentration camps throughout France. French rabbis begged for a public word of support from the episcopate but, until I 942, none came. All public acclaim was reserved for the regime.

Similarly, as the French Catholic Church embedded itself in the state's administrative apparatus and received concessions in return, Jews were being purged from the French political sphere and forced to resign from their posts. Again, rabbis appealed to the Church and sought to remind them of their pre-war relationships. This included the "front for defense for the bible" formed in 1933 by Grand Rabbi Israël Levi and which included bishops and their representatives from France's largest cities [Bernay 20 I 2: 64-66]. The episcopate had no interest in pursuing this alliance.

Concerning the expression of shared values, it would appear thatpublicly, at least-Jews were considered an afterthought. French bishops regularly expressed the National Revolution philosophy as their own and mirrored Pétain's beliefs that Jews did not comprise a natural part of the national community. Privately, Catholic authorities justified the first Statut des Fuifs by describing Jews as unassimilable foreigners. They 
thus provided the government with a soundbite that it then parroted when explaining the rationale for its discrimination.

Finally, the common rhetoric expressed by both Pétain and French bishops further excluded Jews insofar as Pétain cast himself as a Christlike savior. This was reflected in Catholic discourse which the rabbinate could not share. Pétain also frequently drew on symbols such as the image of Joan of Arc to justify his political crusade; in one stained-glass window of Joan of Arc in Orléans, this imagery was accompanied by explicit antiSemitism. While Pétain rarely held a political ceremony without the presence of a Catholic leader, Jews were excluded from the political events in which they had previously taken part.

When combined, these practices reveal precisely how the French Catholic Church became "one of the main actors and arbiters" in the Vichy government's “constant struggle for legitimacy” [Peschanski 2004: 409]. Simultaneously, the results show how the outcomes of these struggles from I 940-I 942 impacted the fate of Jews as the alignment between Church and State led to a concomitant decline in the Catholic leadership's relationship with the rabbinate. Although further research is required to fully assess the impact of these changing dynamics on the Vichy government's ability to secure support, in focusing on the behaviors of Church and State authorities, this article provides an outline for future work to consider how a third actor-the individual-responded to these changes from above.

Likewise, it remains to be seen whether religious organizations as a particular kind of meso-level actor are uniquely able to influence authoritarian legitimation processes or if the practices identified here change depending on the organization being examined. That said, the results reveal how attention to meso-level actors illuminate important dynamics about authoritarian legitimation. As institutions, organizations, and leaders situated in the space between national-level institutions and individuals, meso-level actors shape how rulers' tactics are perceived and received from below. These dynamics are missed when legitimation is treated simply as the product of a relationship between rulers and civilians.

Finally, authoritarians may desire to legitimize their rule and their exclusionary visions of society much like Pétain sought to legitimize himself as France's savior and the National Revolution as the proper course for France. Yet this article argues that without the support of meso-level actors, authoritarians may, in fact, fail to gain widespread acquiescence. In France, once the bishops protested Vichy's treatment of Jews in August I 942, there was a sea-change in public opinion vis-a-vis the regime's anti-Semitic violence and a surge in clandestine activism on 
Jew's behalf, causing deportation rates of Jews to dramatically decline. Hence, what the Church did-how it praised the regime, cooperated with its administration, claimed to share the same values, and mirrored its rhetoric-mattered. Likewise, in any context in which authoritarianism is on the rise, meso-level organizations and leaders' choices to speak out or cooperate are consequential. By attending to the crucial role of these mediators between state and society, we can gain a fuller grasp on the processes at play in the emergence and legitimation of authoritarianism.

\section{$R E F E R E N C E S$}

AdLer J., I 987 . The Fews of Paris and the final solution: Communal response and internal conflicts, I940-I944 (New York NY, Oxford University Press).

—, 200ı. "The Jews and Vichy: Reflections on French Historiography," The Historical Fournal, 44 (4): 1065-1082.

Alagappa M., I995. Political legitimacy in Southeast Asia: The quest for moral authority (Palo Alto CA, Stanford University Press).

Barbas J.C., ed., I989. Philippe Pétain. Discours aux français, I 7 Fuin I 940-20 Aô̂t 1944 (Paris, Albin Michel).

BÉdarida R., I998. Les Catholiques dans la guerre, I939-1945: Entre Vichy et la Résistance (Paris, Seuil).

Bédarida F. and R. Bédarida, 200I. La Résistance spirituelle: I94I-I944: les cahiers clandestins du Témoignage chrétien (Paris, Albin Michel).

Beетнам D., I 99 I. The Legitimation of Power (Houndsmills, MacMillan).

Bernay S., 201 2. L'Église de France face à la persécution des juifs I940-I944 (Paris, CNRS).

Blaydes, 20 Io. Elections and Distributive Politics in Mubarak's Egypt (New York NY, Cambridge University Press).

Braun R., 20i6. "Religious minorities and resistance to genocide: The collective rescue of Jews in the Netherlands during the Holocaust," American Political Science Review, I Iо (I): I 27-I 47.

-, 2019. "Minorities and the Clandestine Collective Action Dilemma: The Secret Protection of Jews during the Holocaust," American Fournal of Sociology, I24 (2): 263-308.

Brownlee J., 2007. Hereditary succession in modern autocracies, World Politics, 59 (5), $595-628$.
Brubaker R., I 992. Citizenship and Nationhood in France and Germany (Cambridge MA, Harvard University Press).

—, 2OI 5. "Religious Dimensions of Political Conflict and Violence," Sociological Theory, 33 (I): I - I 9 .

Burnell P., 2006. "Autocratic Opening to Democracy. Why Legitimacy Matters," Third World Quarterly, 27: 545-562.

Burnell P. and O. Schlumberger, 20 io. "Promoting democracy - promoting autocracy? International politics and national political regimes,” Contemporary Politics, I6(I): I - I 5 .

Burrin P., I 996. Vichy France Under the Germans: Collaboration and Compromise (New York NY, The New Press).

Cassani A., 2017. "Social services to claim legitimacy: comparing autocracies' performance," Contemporary Politics, 23, 3: $348-368$.

Clément J., I999. Les Évêques au temps de Vichy: loyalisme sans inféodation. Les relations entre l'Eglise et l'Etat de I 940 à I 944 (Paris, Beauchesne).

Crane R. F., 2004. "La Croix and the Swastika: The Ambiguities of Catholic Responses to the Fall of France," The Catholic Historical Review, 90 (I), 45-66.

Dimitrov M. K., 2009. "Popular autocrats," Fournal of Democracy, 20 (I), 78-8I.

DrapaC V., I 998. War and Religion: Catholics in the Churches of Occupied Paris. (Washington DC, Catholic University of America Press).

Dukalskis A. and J. Gerschewski, 2017. "What autocracies say (and what citizens hear): proposing four mechanisms of autocratic legitimation," Contemporary Politics, $23(3): 25$ I -268 . 
Dukalskis A. and C. Patane, 20 i 9. "Justifying power: When autocracies talk about themselves and their opponents." Contemporary Politics, 25(4): 457-478.

Duquesne J., I 966 . Les Catholiques français sous l'occupation (Paris, Grasset).

Easton D., I 965. A Systems Analysis of Political Life (Hoboken, John Wiley \& Sons).

-, ( I 975). "A Re-Assessment of the Concept of Political Support," British Fournal of Political Science, 5 (4): 435-57.

Ermakoff I., 2008. Ruling Oneself Out: A Theory of Collective Abdications (Durham NC, Duke University Press).

Finkel E. and S. Straus, 20I2. "Macro, Meso, and Micro Research on Genocide: Gains, Shortcomings, and Future Areas of Inquiry," Genocide Studies and Prevention, 7 (I): 56-67.

Fouilloux E., 1997. Les Chrétiens français entre crise et libération: 1937-1947 (Paris, Seuil).

—, 2002. "Église catholique et seconde guerre mondiale," Vingtième Siècle, 73: I I I-I 24.

Fox J., 2018. An Introduction to Religion and Politics: Theory \& Practice, Routledge Studies in Religion and Politics (New York NY, Routledge).

Gandhi J., 2008. Political institutions under dictatorship (Cambridge UK, Cambridge University Press).

Gandhi J. and E. Lust-Okar, 2009. "Elections under authoritarianism," Annual Review of Political Science, I 2: 403-422.

Geertz C., I 983 . Centers, kings, and charisma: Reflections on the symbolics of power. In Local knowledge: Further essays in interpretive anthropology (New York, Basic Books: I 2 I - I 46).

Georges O., 2003. "Un discours controversé : la réception du Maréchal Pétain à Lyon par le Cardinal Pierre-Marie Gerlier, le 20 novembre I 940," Chrétiens et Sociétés XVIe-XXIe siècles, I о: I 33-I 49.

Gerschewski J., 20I3. "The three pillars of stability: Legitimation, repression, and co-optation in autocratic regimes," Democratization, 20 (I), I 3-38.

一, 20 1 8. "Legitimacy in autocracies: Oxymoron or essential feature?," Perspectives on Politics, I6 (3), 652-665.

Gorski P. S. and G. Türkmen-Dervisoglu, 20I3. "Religion, Nationalism, and Violence: An Integrated Approach," Annual Review of Sociology, 39 ( I): I 93-2 I 0.

Griffioen P. and R. Zeller, 2006. "AntiJewish Policy and Organization of the
Deportations in France and the Netherlands, I 940-I 944: A Comparative Study,” Holocaust and Genocide Studies, 20 (3): 437473 .

Grzymala-Busse A., 20I 5. Nations under God: How Churches use Moral Authority to Influence Policy (Princeton NJ, Princeton University Press).

Grzymala-Busse A. 20i6. "Weapons of the meek: how churches influence public policy," World Politics, 68 ( I): I-36.

Guerry, Monsignor Émile, I 947. L’Église catholique en France sous l'occupation (Flammarion, Paris).

Guhin J., 20I6. "Why Worry about Evolution?: Boundaries, Practices, and Moral Salience in Sunni Muslim and Conservative Protestant High Schools," Sociological Theory, 34 (2): I 5 I -75.

Halls W. D., I 995. Politics, Society, and Christianity in Vichy France (Providence RI, Berg Publishers).

Hechter M., 2009. Legitimacy in the Modern World (Los Angeles CA, Sage Publications Sage).

Hilberg, ( I96I) I 985. The Destruction of the European Fews, 3 vols. (New York NY, Holmes and Meier).

Holbig H., 20I3. "Ideology after the end of ideology. China and the quest for autocratic legitimation," Democratization, 20 (I): 6 I $8 \mathrm{I}$.

ISAACS R., 2010. "'Papa' - Nursultan Nazarbayev and the discourse of charismatic leadership and nation-building in Post-Soviet Kazakhstan", Studies in Ethnicity and Nationalism, I 0 (3), 435-452.

Jackson J., 2003. France: The Dark Years, I940-I 944 (Oxford UK, Oxford University Press).

Johnson C., T. J. Dowd and L. Ridgeway, 2006. "Legitimacy as a social process," Annual Review of Sociology, 32: 53-78

Kailitz S., 20I3. "Classifying political regimes revisited: Legitimation and durability," Democratization, 20 (I), 39-60.

Kailitz S. and D. Stockemer 20 I 5. "Regime Legitimation, Elite Cohesion and the Durability of Autocratic Regime Types," International Political Science Review, 38 (3): 332-348.

KLARSFELD S., I983. Vichy-Auschwitz: Le rôle de Vichy dans la solution finale de la question juive en France, 2 vols (Paris, Fayard). 
Krastev I., 20I I. "The paradoxes of new authoritarianism," Fournal of Democracy, 22(2), 5-I6.

Kselman 2000. "Catholicism, Christianity, and Vichy," French Historical Studies, 23 (3): 5I 3-53O.

LABORIE, 200I. L'Opinion française sous Vichy: Les Français et la crise d'identité nationale, 1936-1944 (Paris, Seuil).

Lee C. K. and Y. Zhang, 20 I 3. "The Power of Instability: Unraveling the Microfoundations of Bargained Authoritarianism in China," American Fournal of Sociology, I I 8 (6): I 475 -I 508 .

Le Moigne F. L., 2005. Les Évêques français de Verdun à Vatican II: une génération en mal d'héroïsme (Rennes, Presses universitaires de Rennes).

Levitsky S. R. and L. A. WAy, 2010. Competitive authoritarianism: Hybrid regimes after the Cold War (Cambridge UK, Cambridge University Press).

—, 20I 2. "Beyond Patronage: Violent Struggle, Ruling Party Cohesion, and Authoritarian Durability," Perspectives on Politics, I $\circ$ (4): 869-889.

Linz J. J., 2000. Totalitarian and authoritarian regimes (Boulder CO, Lynne Rienner Publishers).

Lubac (de) H., I990. Christian resistance to anti-Semitism: Memories from I 940-I 944 (San Francisco, Ignatius Press).

LufT A., 2016. "Shifting Stances: How French Bishops Defected from Support for the Anti-Semitic Vichy Regime to Save Jews during the Holocaust," (PhD diss., University of Wisconsin-Madison).

Magaloni B., 2006. Voting for Autocracy: Hegemonic Party Survival and its Demise in Mexico (Cambridge UK, Cambridge University Press).

-, 2008. "Credible power-sharing and the longevity of authoritarian rule," "Comparative Political Studies, 4I : 7 I 5-74I.

Marrus and Paxton [I98I] I995. Vichy France and the fews (Stanford CA, Stanford University Press).

McAdam D., I 982. Political Process and the Development of Black Insurgency, I930I 970 (Chicago IL, The University of Chicago Press).

Morris A. D., I 984 . Origins of the Civil Rights Movements: Black Communities Organizing for Change (New York NY, Free Press).

Nord P., 2003. "Catholic Culture in Interwar France," French Politics, Culture, and Society, 2 I : I-20.
Paxton R., I972. Vichy France: Old Guard and New Order, I 940-I 944 (New York NY, Columbia University Press).

Peschanski D., 2004. "Legitimacy/Legitimation/Delegitimation: France in the Dark Years, a Textbook Case," Contemporary European History, I 3 (4), 409-423.

Philpott D., 2007. "Explaining the Political Ambivalence of Religion," American Political Science Review, I I I (3): 505-525.

Pinto M., 20I2. "Nationalist Symbol of a Nation Divided: The Paradox of France's Joan of Arc, I 940-I 944," [Available electronically from http://hdl.handle. net/roo66/8 I 6 I].

Poznanski R., 2001. Fews in France during World War II (Waltham MA, Brandeis University Press in association with the United States Holocaust Memorial Museum).

Pury R. D., I 978. "Les Églises et les chrétiens à l'automne I 944," Revue du Nord, 60 (238) [Églises et Chrétiens pendant la Seconde Guerre Mondiale: Les colloques de Lyon et de Varsovie]: 729-733.

Reuter O. J. and J. Gandhi, 20I I. "Economic Performance and Elite Defection from Hegemonic Parties," British Fournal of Political Science, 4I: 83-I Io.

Reuter O. J. and D. Szakonyi, 20i 9. "Elite Defection Under Autocracy: Evidence from Russia," American Political Science Review, I I 3 (2): 552-568.

Rousso H., I991. The Vichy Syndrome: History and Memory in France Since 1944 (Cambridge MA, Harvard University Press).

SAPIRO, G. 20I 4. The French Writers' War, I 940-I 943 (Durham NC, Duke University Press).

ScharpF F. W., (I 999). Governing in Europe: Effective and Democratic? (Oxford UK, Oxford University Press).

Schatz E., 2006. "Access by accident: Legitimacy claims and democracy promotion in authoritarian Central Asia”, International Political Science Review, 27 (3), 263-284.

Schedler A., 2002. "The menu of manipulation, " Fournal of Democracy, I 3 (2): 36 50.

-, 2013. The politics of uncertainty: Sustaining and subverting electoral authoritarianism (Oxford, Oxford University Press).

Seibel W., (2016). Persecution and Rescue: The Politics of the "Final Solution" in 
France, I 940-I 944 (Ann Arbor, University of Michigan Press).

Slater D. and E. Simmons, 20 io. "Informative Regress: Critical Antecedents in Comparative Politics," Comparative Political Studies, 43 (7): 886-9I 7.

Svolik, M., 2009. "Power-sharing and Leadership Dynamics in Authoritarian Regimes," American Fournal of Political Science, 53 (2): 477-94.

Sмiтh C., I 996 . "Correcting a Curious Neglect, or Bringing Religion Back in," in Sмiтн C., ed., Disruptive Religion: The Force of Faith in Social Movement Activism (New York, Routledge: I-28).

Staggenborg, i 99i. The Pro-Choice Movement: Organization and Activism in the Abortion Conflict (Oxford UK, Oxford University Press).

Tallett F. and N. Atkin, i 99i. Religion, Society and Politics in France since 1789 (London UK, Hambledon).

Tannenberg M., M. Bernhard, J. Gerschewski, A. Lührmann and Chr. vON SoEst, 2019. "Regime Legitimation Strategies (RLS): I 900 to 2018 ," The Varieties of Democracy Institute (Working Paper, Series 20 I 9: 86, University of Gothenberg).
VINEN R., 2006. The unfree French: Life under the Occupation (New Haven, Yale University Press).

Von Soest C. and J. Grauvogel, 2017. "Identity, Procedures and Performance: How Authoritarian Regimes Legitimize Their Rule," Contemporary Politics, 23(3): 287-305.

WEBER M., [1 922] I 978. Economy and society: An outline of Interpretive Sociology (G. Roth, Trans.; C. WiтTich, ed.) (Berkeley, University of California Press).

-, [I 9 I 9] 2004. The vocation lectures (Indianapolis, Hackett).

Wieviorka O., 20I6. The French resistance (J. M. Todd, Trans.) (Cambridge MA, Harvard University Press).

Williams R. H., I 996. "Religion as political resource: Culture or ideology," Fournal for the Scientific Study of Religion, 35 (4): 368-378.

$Z_{\mathrm{ALC}}$ C., 20I6. Dénaturalisés. Les retraits de nationalité sous Vichy (L'Univers historique, Paris, Éditions du Seuil).

ZALD M. N. and J. D. MCCARThy, I 987. "Religious Groups as Crucibles of Social Movements," in M. N. ZALD and J. D. McCarthy, eds, Social Movements in an Organizational Society (New Brunswick NJ, Transaction Books). 


\section{RELIGION IN VICHY FRANCE}

\section{Résumé}

Les recherches sur la légitimation autoritaire suggèrent que les dirigeants cherchent un soutien par des stratégies idéologiques, personnalistes, basées sur la performance et les procédures. Cependant, ces travaux ne prennent généralement en compte que les dynamiques de légitimation entre les dirigeants et les civils. À l'opposé, cet article suggère que les acteurs de niveau méso jouent un rôle essentiel dans la formation de la légitimation par le haut et par le bas. À travers l'analyse historique du soutien de l'épiscopat français au régime de Vichy de 1940 à 1942, j'identifie quatre pratiques qui ont soutenu les tentatives de Vichy pour accroître la légitimité et j’identifie simultanément les conséquences de ces pratiques sur la relation de l'Église avec les Juifs. Le soutien public des autorités religieuses au maréchal Pétain, leur coopération avec l'administration de Vichy, l'expression de valeurs partagées et une rhétorique commune ont tous contribué au processus de légitimation du régime tout en conduisant à un déclin concomitant des liens de la hiérarchie avec le rabbinat. Ces résultats suggèrent que l'attention portée aux acteurs de niveau méso met en évidence des dynamiques importantes sur la façon dont les processus de légitimation se déroulent dans des contextes autoritaires tout en contribuant simultanément à la recherche sur la Shoah en France.

Mots-clés : Autoritarisme ; France ; Légitimité ; Religion ; Vichy.

\section{Zusammenfassung}

Forschungen zur autoritären Legitimation legen nahe, dass Führungskräfte zu ihrer Unterstützung ideologische, personalistische, leistungsbezogene und prozedurale Strategien mobilisieren. Diese Forschungen berücksichtigten jedoch im Allgemeinen nur die Legitimationsdynamik zwischen Führern und Zivilisten. Im Gegensatz dazu legt dieses Papier nahe, dass Akteure auf der Mesoebene eine Schlüsselrolle bei der Legitimationsbildung von oben und unten spielen. Das französische Episkopat hat das Vichy-Regime zwischen 1940 und 1942 unterstützt; die geschichtswissenschaftliche Untersuchung lässt vier Praktiken erkennen, durch die das Vichy-Regime seine eigene Legitimität erhöhen konnte und die gleichzeitig aufzeigen, wie sich die Beziehung der Kirche zu den Juden aufgrund dieser Unterstützung verändert hat. Die öffentliche Unterstützung Marschall Pétains durch religiöse Autoritäten, die Zusammenarbeit mit der Vichy-Regierung, die Zurschaustellung gemeinsamer Werte und eine gemeinsame Rhetorik trugen zum Legitimationsprozess Vichys bei und führten gleichzeitig $\mathrm{zu}$ einem Bindungsverlust der Kirchenhierarchie an das Rabbinat. Diese Ergebnisse deuten darauf hin, dass die den Akteuren der Meso-Ebene geschenkte Aufmerksamkeit entscheidende Dynamiken freilegt, wie z.B. Legitimationsprozesse in autoritären Kontexten, und gleichzeitig einen Beitrag zur Shoah-Forschung in Frankreich leistet.

Schlüsselwörter: Autoritarismus; Frankreich; Legitimität; Religion; Vichy. 